\title{
中国の燃える野望が地球環境を劦かす China's burning ambition
}

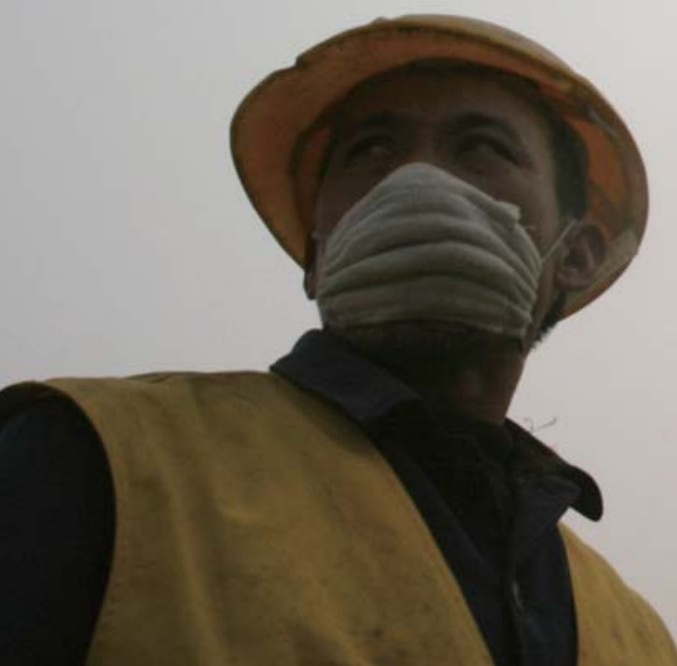

中国の経済発展は、世界最多の人口を抱えるこの国を変ぼうさせている。しかし、エネルギー不足と環境污染の激化が、奇跡 の発展をはばむ課題として浮上してきた。とくに環境への影響は、地球全体の気候を大混乱に追い込む危険性もはらんでいる。 Peter Aldhous が報告する。

中国経済は今、急成長しており、エネ ルギーはいくらでも欲しい。しかし、 中国のほとんどの場所で大気はひど く污染されており、このことは中国が エネルギー源を石炭などの「污い」燃 料に頼っていることをいやでも思い 出させる。私が中国のエネルギー政策 を担当している技術官僚に会うため に北京を訪れたとき、北京は刺激性の スモッグで覆われていた。風のない天 候がわずか数日間続いただけで、視界 が数十メートルに落ちた地区もあっ た。航空便は遅れ、北京市環境保護局 は人々に屋内にいるように忠告した。 空気に硫黄の味を感じることさえで きそうだった。

エネルギー供給の問題とエネルギー 消費が環境や健康におよぼす影響の問 題は、中国の重要な政治的課題だ。し かし、中国の指導者たちの対処法は現
実的で、私たちはとまどうことになる だろう。中国のエネルギー政策は、石 炭をその基盤にし続けるだろうが、石 炭は、よく知られているように環境に よくない燃料だ。これを、クリーンな ものにすることができるか否かが、中 国の今後の発展と地球全体の気候の長 期的な安定性を左右するかぎとなる。

中国にとって目前の問題は、経済成 長がすでにエネルギー供給を上回って いることだ。広東省の深圳( シェンチ エン)や四川省の成都 (チョントゥー ) などの新興都市では今、電力供給が不 安定になっている。昨年、中国の 31 の省、地方自治体、自治区のうち 24 が、 電力が不足していることを認めた。夏 になると、降水量の減少で水力発電量 が減り、またエアコンが急速に普及し ているために、停電は日常的な出来事 となっている。
中国の炭鉱は、需要を満たすために 懸命に努力しているが、同時に多数の 人命を犠牲にしている。控えめな公的 な推計によると、昨年中国の鉱山で死 亡した労働者は 6000 人をこえる。中 国の鉱山は世界で最も危険な鉱山にな っている。2005 年上期も死亡率は下 がっていない。

しかし、石炭からの大気污染による 犠牲者についてのほとんどは、ニュー スで大きく扱われない。中国の都市の 多くは、大気の質の国際基準を(ある いは国内基準も ) 満たしておらず、年 間数十万人が若くして死亡している。 石炭の使用量の増加は二酸化炭素の放 出量を急増させており、地球規模の気 候変動の危険性をもたらしている。北 京にある国家発展改革委員会能源研 究所 (エネルギー研究所) のZhou Dadi( 周大地) 所長は「石炭はエネル 
ギー源であるだけでなく、長期的には 社会や環境に影響することを私たちも 理解している」という。Dadi は、工 ネルギー戦略について中国の指導者に 助言する指導的アドバイザーのひとり だ。

Dadi ら上級のエネルギー計画立案 者は、こうした問題を認識してはい るが、今後も石炭を使い続けようと いう意思は固い。中国の指導者たち は 2020 年までに経済の規模を 4 倍に することを目指しており、そのために はエネルギー供給を少なくとも現在の 2 倍にすることが必要だ。そのほとん どを石炭が担うことになるだろう。能 源研究所のエネルギーシステム分析の 専門家であるGuo Yuan は「私たち は、石炭の消費を増やさなければなら ない。それはよい状況とはいえないが、 そうせざるをえない」と話す。

輸送部門のエネルギー需要は急速に 増大しているが、最も多くのエネルギ 一を使っているのは発電だ。中国の電 カの 75 ～80\% は石炭を燃やしてつく られている。20\% は大規模水力発電で、 残りのほとんどは原子力発電所だ。今 のところ、石油や天然ガス、風力など の再生可能エネルギーが発電量に占め る割合はほんのわずかだ。しかし、公 式な見積もりによると、2020 年まで には中国の電力需要の $15 \%$ をガス発 電がまかない、原子力発電も約 $5 \%$ に 増える可能性がある。また、今年 2 月 に再生可能エネルギ一利用を促進する 法律が成立したため、風力などの再生 可能エネルギーも $10 \%$ を占めるよう になるかもしれない。しかし、同じ期 間に電力需要は少なくとも 2 倍になる のだから、石炭消費量の大幅な増加が 避けられないことは明らかだ。

ベテランの中国問題専門家によると、 経済成長を維持することは中国指導層 の優先事項だが、彼らはそれをエネル ギ一安全保障を危うくすることなく達 成したいのだという。中国の石油と天 然ガスの埋蔵量は豊富ではなく、中国 政府はこれらを輸入に大きく依存しな いことを決めている。中国には石炭は
豊富にある。中国がロシアの石油と天 然ガスに依存することは、将来、この 2 大国を戦争の瀬戸際に追い込む可能 性もある。だから、これを避けるため に中国は石炭を今以上に使うだろう。

しかし、環境を污染することなく、 また、数百万人の人々が粒子状物質や 硫黄酸化物、窒素酸化物を吸入するこ となしに、エネルギー需要を満たすこ とができるのだろうか。酸性雨の影響 は広がっており、すでに「すす」によ って、この地域の気候が変化している という指摘もある (別項の「褐色雲の 暗(影」を参照)。

地球規模の気候変動はまだ、中国の 指導者たちにとって大きな懸念にはな っていない。しかし、二酸化炭素の放 出という点では石炭は最悪のエネルギ 一源だと、国際的に活躍している専門 家たちは警告している。新華 BP 清潔 能源研究与教育中心 ( 新華 BP クリー ンエネルギー研究教育センター)を指 揮しているLi Zhengは、「地球規模 での問題は気候変動だ。しかし、中国 にとっての主要な問題は従来型の環境 污染だ」と説明する。同センターは北 京の一流理工系大学と英国のエネルギ 一企業の協力で設立された。

\section{石炭は万能}

エネルギーの利用効率を向上させるこ とは、環境污染を抑制しながら経済成 長を促進する、最も容易な方法だとい うことを中国のエネルギー計画立案者 たちは理解している。「中国は、まず工 ネルギー利用効率の改善に取り組むべ きだ」とDadi は話す。「産業活動がこ れまでどおり」と仮定した予測による と、全エネルギー需要は 2020 年まで に石炭換算で年間 35 億トン相当に増 加するだろうという。しかし、「エネル ギ一利用効率を改善する手段をひとと おり導入すれば、これを 30 億トン未 満に抑えることができる。技術的には 可能だ」と Dadi はいう。

このようにエネルギー効率の向上 を目指そうとする新しい動きが中国に 出てきた背景には、ひとつには、米国
サンフランシスコにある「エネルギー 基金」が地味だが影響力のある活動を 行ってきたことが挙げられる。同基金 の「中国持続可能エネルギープログラ ム」は、ヒューレットパッカード財団 から 1999 年以来計 4000 万ドル ( 約 45 億円 ) の資金提供を受け、中国の工 ネルギー研究者とともにエネルギー効 率を改善し、環境污染を減らす活動を 行っている。優先的に取り組む課題は、 建築物、電気器具類、乗り物のエネル ギー効率の新しい基準づくりや、再生 可能エネルギー源の利用促進などだ。 エネルギー基金の北京事務所長である Yang Fuqiang (楊富強) は最近の活 動成果として、再生可能エネルギー法 や、中央政府や地方自治体に採用され た燃料効率基準、エネルギー効率向上 のための建築規則などを挙げる。

エネルギー利用効率の向上は立派 な目標だが、中国はさらなる成長を求 めているのに、政府の指導者たちは石 油の輸入を制限したいと考えている以 上、それだけでは不十分だ。だから、 西側諸国ではあまり重視されていない 技術を中国は進んで採用している。北 京石炭化学研究所長の Du Minghua は、石炭は万能のエネルギー源であり、 中国が必要とする電力、液体燃料、ガ スの需要をすべて満たすことができる と考えている。Minghuaは、同研究 所での石炭ガス化と石炭液化の研究に ついて発表を始める前に「石炭は $3 つ$ の需要全部に対する答えとなる」と声 を大にして強調した。

石油への依存を減らす方法を探す ことは、輸送部門ではきわめて重要 なことであり、Minghua の研究所の 最優先課題だ。褐炭などののように生 成年代の新しい石炭は、水素と適当な 触媒を用いて 450 度 Cに熱すると直 接、液体燃料に変えることができる、 とMinghuaは説明する。無煙炭など の生成年代の古い石炭は、まず熱して 合成ガスとよばれる水素と一酸化炭素 の混合物をつくる必要がある。この合 成ガスは液体燃料に変えることができ る。できた液体燃料には、ディーゼル 
燃料と混ぜれば従来のエンジンに直接 注入できるものもある。

石炭から直接液体燃料をつくる技術 に対して西側諸国の専門家は懐疑的だ が、中国国営の「神華集団公司」は、 世界初の商業的石炭直接液化工場を内 モンゴル自治区に建設中で、完成は 2008 年までと予定されている。さら に中国は、南アフリカの企業「サソー ル」と、2 つの大型間接液化工場建設 の可能性について協議中だ。

\section{合成ガス都市}

しかし、直接液化、間接液化のいずれ のプロセスもエネルギー効率の面では 模範となるものではない。直接液化の エネルギー効率は約 60\%であり、間 接液化の場合は約 45\%だ。しかし、 中国は代替液体燃料を強く求めてお り、液化技術によって 2020 年までに 年間 5000 万トンをこえる量の液体然 料が供給されるようになる可能性があ るとMinghuaは見積もる。「これは、 個人的な見積もりだ」と彼は強調する。 しかし、この見積もりは中国の指導者 たちにとっては喜ばしい話だろう。も し Minghua の予測が正しければ、石 炭液化は中国の原油需要を年間 1 億 トン分減らすかもしれない。これは、 2020 年までに予想される輸入量の約 3 分の 1 に相当する。

石炭問題は、新華 BP 清潔能源研究 与教育中心の研究者たちにとっても中 心的なテーマだ。Zhengは、ひとつ の工場で石炭を合成ガスに変え、それ をガスタービンに利用して発電し、し かも合成ガスを液体燃料に変えるとい う「ポリジェネレーション」という技 術を重点的に研究している 2 。硫黄は、 ガス化に必須なプロセスで取り除かれ るので環境污染も減る。この技術の可 能性を立証するため、Zhengらは、 中国東部にある山東省の東荘 (チァオ チョアン) をモデルに「合成ガス都市」 のシミュレーションを行った。中国の 多くの産業の中心地と同じように、霜 荘は大きな問題に直面している。たや すく利用できる燃料が硫黄分の多い石

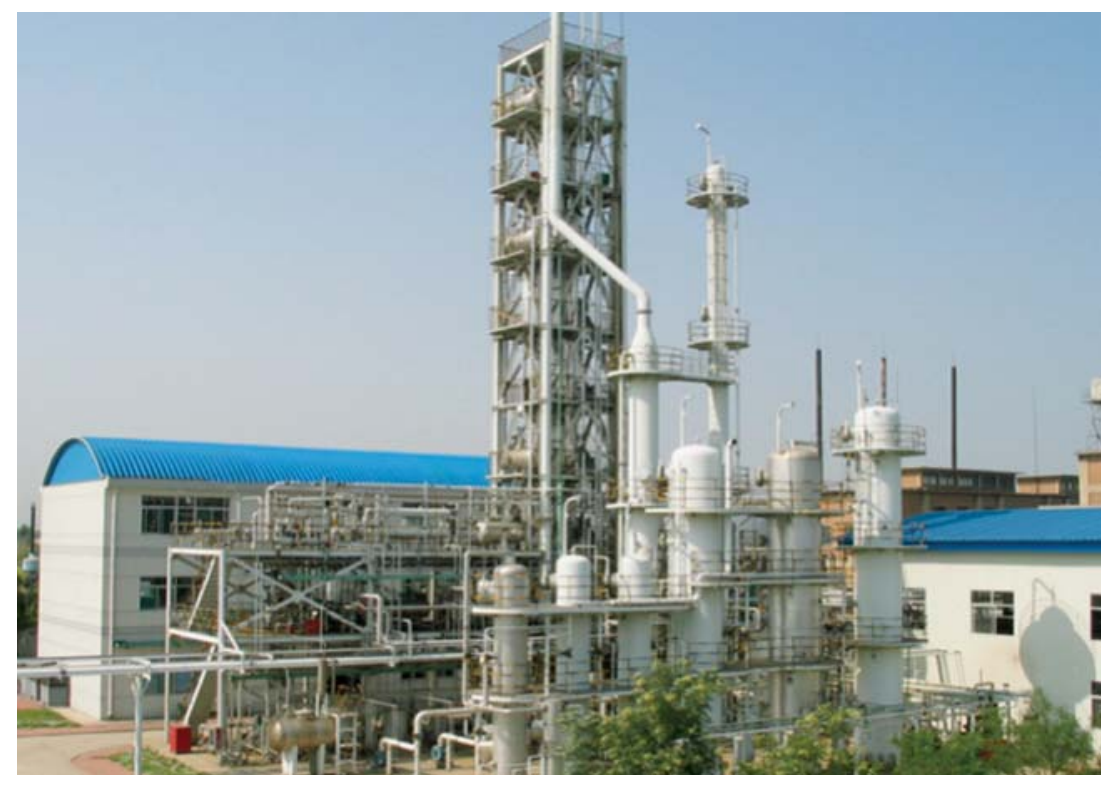

石炭液化などの研究をしている石炭化学研究所

炭だけの場合、どうすれば成長を続け ることができるか、という問題だ。

「合成ガス都市」のシミュレーション では、霜荘市当局は、ポリジェネレー ションを促進するための補助を与える。 ポリジェネレーションでは、発電する だけでなく、乗り物の燃料となるメ夕 ノールと家庭の料理と暖房用のジメチ ルエーテルがつくられる。このシミュ レーションは、ポリジェネレーション は 2020 年までに霜荘の電力需要の 4 分の 1 をこえる電力を供給できるかも しれないことを示した。また、二酸化 硫黄の放出を劇的に減らす一方、従来 の発電所での高コストな排煙脱硫技術 に投資する必要性も小さくなる ${ }^{3}$ 。メ夕 ノールとジメチルエーテルの利用が広 がれば、オゾン前駆体物質などの大気 中の污染物質の削減にもつながる。

このようなシミュレーションは、世 界中のエネルギー問題研究者がつねに 行っている。しかし、中国では、当局 がその意図するところを国民に強制す る権力が他国よりも強い。このため、 シミュレーションしたことが実際に実 行される可能性は高いかもしれない。 2008 年に開かれる北京オリンピック に向けた準備は、その好例だ。北京市 は今、ひどい大気污染が選手たちの健 康を損なうかもしれない(そして、世
界に中国の悪い印象を与える ) ことを 悟り、大急ぎで大気の浄化に取り組ん でいる。環境污染のひどい約 200 の工 場を閉鎖し、天然ガスのパイプライン をひき、クリーンな高度基幹バスシス テム (BRT) を導入しているところだ。 北京にある環境保護団体「北京地球縦 観環境科普研究中心」( 北京アースビ ユ一環境教育研究センター) の代表、 Li Hao は「オリンピックは、( 環境改 善の) きわめて大きなチャンスだ」と 話す。

Zheng らは、政府も環境の健康に 与える影響について懸念を強めている ことは、約 50 億元 ( 約 680 億円) を 必要とするポリジェネレーション実証 工場の建設という自分たちの提案にと って追い風となるだろうと期待してい る。この実証工場は、最大 40 万キロ ワットの電力と年間 40 万トンもの液 体燃料を作り出すはずだ。「私たちは、 政府からとてもよい返事を得ている」 とZhengはいう。

\section{中国を仲間に}

ポリジェネレーションやそのほかのク リーンな石炭技術は、中国の污れた空 気の浄化に役立つかもしれないが、中 国の増加している温室効果ガス放出を 抑制するためには、短期的にはあまり 


\section{褐色雲の暗い影}

6 月に入って、中国では各地で ひどい洪水が起こり、洪水の季 節が正式に始まった。過去 20 年間で南部では夏期の洪水が、 北部では干ばつが増加してき た。原因として考えられるのは 大気污染だ。污染は中国の工業 生産の急速な拡大で悪化してお り、この地域の気候を变化させ るかもしれない。

中国の気候変化の主犯は、ア ジアを覆っているエアロゾル ( 煙霧質 ) だ。污染の原因は中 国だけではない。インドは、褐 色雲とよばれるスモッグの形成 に大きく関与している。スモッ グの主成分は、黒色炭素 (元素 状炭素)、有機炭素 (有機物に 含まれる炭素) と、その他硫酸 塩や硝酸塩などのエアロゾルで あり、野火や化石燃料、生物燃 料の燃焼で発生する。

黒色炭素はすす状の炭素燃焼 の副産物で、太陽光を吸収して 大気の温度を上げ、地面の温度 を下げる効果がある。すす状の 粒子は水滴ができる際の種とな るために、小さな水滴の形成は
促進するが、大きな水滴の形成 を妨げる。その結果、降雨にも 影響する。この効果は雲の形成 を促すが、降水量は減少させる。 ニューヨーク市にある米航空宇 宙局 (NASA) ゴダード宇宙科学 研究所の Surabi Menon が率い る研究チームは、ここ数十年間 に中国で観測された降雨パター ンの変化をシミュレーションで 再現するために、黒色炭素放出 を考慮した全球気候モデルを用 いた 4 。気候学者たちはエアロ ゾル污染が中国の降雨パターン を変えたことにはおおむね同意 しているが、污染が地域におよ ぼしうる影響については慎重だ。

アイオワ大学の George Carmichael は「私たちが利用 できる測定結果は不十分で、モ デルもまだ不完全だ」と話す。 エアロゾル放出量の信頼できる 測定は不足しており、黒色炭素 についてはとくにそうだ。また、 気候モデルに関しても、たとえ ばエアロゾルはどのように雲を 変化させるのかなど、はっきり しないことが多い。

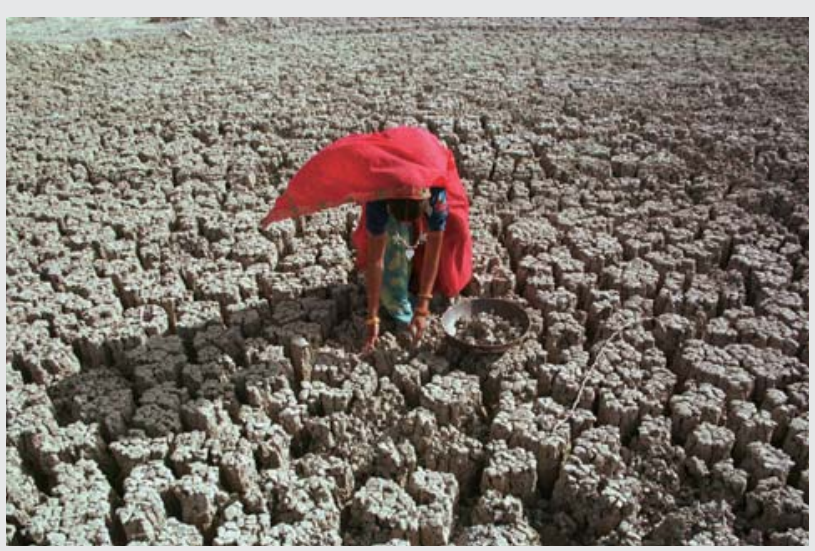

2000 年のインド・ラジャスタン州における干ばつの被害

とはいえ、別の研究でも同じ ような結果が示されている。米 国カリフォルニア州ラホーヤに あるスクリプス海洋学研究所の Veerabhadran Ramanathan らは、エアロゾル污染がイン ド洋北部に変化を起こしたため に、インドではモンスーンによ る降雨が減り、干ばつが増大し たことを示した ${ }^{5}$ 。同じように、 中国の大気污染が周囲の海洋に 影響し、この地域のモンスーン による降雨を変化させている可
能性がある」とRamanathan はいう。

次のステップは不確実性を 減らすことだ。国連環境計画 (UNEP) が行っている「褐色雲 国際研究 $(A B C)$ プロジェクト」 は今年、アジアのスモッグの監 視を始めた。人工衛星による工 アロゾル測定の進歩と、放出モ ニタリングを強化する中国の計 画も、中国の大気污染の程度と 影響の把握に役立つだろう。

Carina Dennis
役立たないだろう。Zheng のシミュ レーションによると、発電所から出る 二酸化炭素の総量は、霜荘が従来の技 術を使い続けている場合よりも、「合成 ガス都市」となった場合の方が多くな るだろうという 3 。

しかし、長期的にみれば、ポリジ エネレーションは持続可能な未来への 道となるかもしれない。合成ガスから 水素を抽出して燃料電池に供給する一 方、二酸化炭素を捕獲し、隔離するの だ。「しかし、そこにいたるまでにはば く大な投資が必要だろう」とZheng は楽観してはいない。

炭素隔離に対する中国の関心は、そ れに必要なコストを考えれば、欧州、 北米、日本がどれだけお金を出す意思 があるかに大きく左右されるだろうと 専門家たちはみている。中国政府は有 利に交渉をまとめたい考えだが、エネ
ルギー産業の現場で働く人たちはその ような政府の意図には無頓着だ。もし、 必要な金が用意されていないなら、炭 素隔離に関するすべての取引は取りや めだ、ということになってしまう。

中国は、温室効果ガスの放出量を 抑制しようとするほかのすべての国の 努力を帳消しにするのに十分な量の二 酸化炭素を一国で放出する可能性があ る。だから、中国の指導者たちは、交 渉の上で強い立場に立てるかもしれな い。米国メイン州ガーディナーにある $N P O 「$ 規制援助計画」の理事である David Moskowitz は「もし中国の産 業活動がこれまでどおりなら地球はお しまいだ」と話す。彼は、中国の当局 者に発電部門の改善についてアドバイ スしている。

このことは、今年 7 月に地球温暖化 を議題にスコットランドに集まった主
要 8 か国 (G8) の首脳たちに考える材 料を与えたはずだ。中国は、気候変動 に関する京都議定書の署名国だが、発 展途上国とされ、放出量の削減目標を まだ課せられていない。世界の指導者 たちが地球を救うためにいかなる戦略 を編みだすにせよ、遅かれ早かれ、中 国を巻き込む必要がある。そして、そ れには相当の費用もかかるはずだ。

Peter Aldhous は、Nature のニュースと特 集記事欄のチーフエディター。

1. Williams, R. H. et al. Energy Sustain. Dev. 7, 103-129 (2003).

2. Zheng, L. et al. Energy Sustain. Dev. 7, 57-62 (2003).

3. Hongtao, Z. et al. Energy Sustain. Dev. 7, 63-78 (2003).

4. Menon, S. et al. Science 297, 2250-2253 (2002). 5. Ramanathan, V. et al. Proc. Natl Acad. Sci. USA 102, 5326-5333 (2005). 